\title{
The Effect of Product Variety on Inventory Turnover in Different Modes of Operation
}

\author{
Junaid Ali Khan \\ Shiming Deng \\ Muhammad Hammad A.K. Khan \\ Huazhong University of Science and Technology, China
}

doi: 10.19044/esj.2017.v13n4p51 URL:http://dx.doi.org/10.19044/esj.2017.v13n4p51

\begin{abstract}
We study the effects of product variety on operational metrics inventory turnover and on sales in different mode of operations. Research has shown that performance metrics can vary in different mode of operations. Using 41 months of data from a large retailer, we show that correlation of product variety with inventory turnover and sales is not always negative or positive as shown in previous studies. This correlation can vary depending upon the mode of operations and type of product. Our study highlights impact of increased product variety on inventory turnover and sales in different mode of operations that has previously been overlooked in studies of retail product variety and inventory management. It also quantifies the impact of product variety on inventory turnover and sales.
\end{abstract}

Keywords: Product variety, Inventory turnover, modes of operation, retail

\section{Introduction}

In traditional retailing channel structure, retailers were buying the stock from multiple manufacturers and then sell them to customers as known as reseller mode. Recently, manufacturers and retailers are forming new contractual relationships to minimize their risk and conflicts and increase the profit. Manufacturers are either renting space from the retailer to reach to customer directly or forming a revenue sharing partnership with the retailer. In this distribution mode the manufacturer pays the retailer a fraction of total sales revenue produced in the store or a fixed amount. First contribution of this research is to add to the existing literature on product variety and inventory management by studying the impact of high product variety on inventory turnover in different modes of operations, which has been missing from the literature. In literature mainly the effect of price in different mode 
of operations have been studied. This study extends that research to product variety.

Increased product variety and inventory levels at retail stores are usually linked with higher sales. Having more variety of products available at a store increases the likelihood that customers will make a purchase by finding what they want (Baumol and Ide 1956). Having more inventory of a particular product increases sales by reducing the chance of stockout. In this paper, using 41 months of data from a large retailer, we empirically test the direct correlation between inventory turnover and product variety and also try to confirm the theories that higher product variety lead to higher sales.

Empirical evidence is presented in this paper to support earlier theories that increased product variety and inventory levels improve sales performance. Although several studies have postulated a negative relationship between product variety and quality, empirical evidence for this assertion has been limited, except for Fisher and Ittner (1999). For long time firm performance has been improved with the help of product variety. It is for the most part expected that a firm can raise its market share by expanding its product variety and consequently attract a bigger and more diverse costumers (Ho and Tang, 1998). For instance Coca-Cola Co., for a quite some time now has embraced this strategy of introducing new brands, flavors, and packages on a regular basis. They introduced ten new flavors just between 2008 and 2009 while an additional 18 flavors in 2010 (CocaCola Co. press center, 2011). But increased product variety is not always related with higher sales. For example, sales increased by $10 \%$ when Procter \& Gamble Co. reduced the depth of its Head and Shoulders shampoo from 26 to 15 (Schwartz, 2000; Osnos, 1997).

Because of the different impact on product variety, operational and marketing wise, it is hard to deduce the overall effect. The result relies on upon the exchange off between these opposite forces. As the importance and effectiveness of product variety strategy can play an effective role in the overall impact of marketing and operational side, its determination can have essential consequences.

An important contribution of our study is to explore the joint operational and marketing impact of product variety on performance metrics in different mode of operations, especially, the difference between effects of product variety on inventory turnover and sales in distribution and reseller mode. While product variety has been studied previously in the economics and marketing literature, such product variety questions typically have not been addressed directly. 


\section{Literature Review}

Jia et al (2016) did first comprehensive study that directly analyzes the consequences of distribution mode on performance measures. After shifting to distribution the retail price on average is decreased and sale increased compared to reseller mode for cell phone and watch category. In another related study, Abhishek et al. (2015) theoretically examined the price implications when an online retailer decides to change from the traditional reselling arrangement (i.e., reseller) to agency selling (similar to distribution) in a multi-channel retailing environment (online and offline) where sales in one channel might have an effect on sales in another channel. Jerath and Zhang (2010) used a theoretical model for studying the store-within-a-store phenomenon, which is essentially the same as distribution mode. They have shown that the more competition decreases retail prices but manufacturers are still capable of enjoying higher profits.

A good number of papers have studied the different product variety strategies notably the work by (Berry and Cooper, 1999), (Closs et al., 2008) and (Salvador et al., 2002). This work can be divided into two main classifications: first one which deals with the methods for optimized implantation of a high product variety strategy and second one with the influences of product variety on performance metrics.

Based on customer segmentation and variety-seeking, sales can be increased by a high variety strategy. By providing a large product variety to the customers the demands of different customer segments could be fulfilled (Kekre and Srinivasan, 1990; Xia and Rajagopalam, 2009). Given variance in consumer preferences, increasing the number of products at a store increases the choice set for the customer and is assumed to increase the likelihood that the customer will buy something (e.g., Baumol and Ide 1956, Smith and Agrawal 2000, van Ryzin and Mahajan 1999). Moreover, customers who are variety-seeking and prefer a large choice set are often inclined to choose new products when they are introduced (Smith and Agrawal, 2000). In addition, increasing the number of products within a category increases the number of substitutes within that category and hence potentially decreases lost sales when customers cannot find their first choice (Mahajan and van Ryzin 1999). Thus, a retailer can increase sales to varietyseeking consumers, and a distributor can increase sales to a retailer, by introducing new products and expanding its product line (Kekre and Srinivasan, 1990).

Many studies have explored the effect of product variety on sales. That literature can be split into two main types: one that deals with the marketing side and another one with operations management. In the marketing literature, increase in product variety has been associated with increasing the probability of completing a sale by satisfying the needs and 
wants of diverse consumers. Therefore more product variety can increase sales by costumer segmentations and appealing to variety-seeking shoppers (Bayus and Putsis, 1999; Xia and Rajagopalam, 2009). Conversely, marketing research has also found the evidence of selection confusion among customers in case of excess product variety (Thompson et al., 2005). On the operation management side of literature researchers argue that managing inventory can be difficult in case of higher product variety which then reduces the operational performance and results in sales decline (Alfaro and Corbett, 2003; Fisher and Ittner, 1999; Ton and Raman, 2010).

Increase in product variety can make it harder to accurately forecast the demand and avoid stockout, which results in product supply and demand. In industries where product substitutes are imperfect, such as the cars, customers might backorder in the case of a stockout. However, in other industries, such as soft drinks and breakfast cereal, product can be easily substituted. Although, sales may not be lost if substitution occurs within a supplier's product offering (Zahorik, 1994), lost sales will happen when product substitution takes place across suppliers (Wagner and Friedl, 2007). Thus, stockouts that result from a high product variety strategy may ultimately hurt sales performance.

Our research expands on prior work on retail inventory and assortment management. The relationship between stock levels, item assortment, and sales has been examined widely in the operations management and marketing literature. Various studies analyze the impact of inventory on sales performance. In stochastic inventory theory, raise in inventory levels prompts to an increase in expected sales (Cachon and Terwiesch 2006, Silver et al. 1998). Since customer might be all the more ready to visit a store when they expect a high service level (Dana and Petruzzi 2001), increase in inventory also increases sales because of prompting customer demand (Larson and DeMarais 1990).

In macroeconomics the researchers have also begun to give attention to new products or product variety. According to research there is a decline in consumers spending on products that exhibits little variety (Bils and Klenow 2001). Many studies show that given a choice, consumers usually favor more variety (Baumol and Ide 1956, Kahn and Lehmann 1991). A decent number of researches have been accepted that, keeping other things constant (e.g., costs, shelf space), offering more variety is better (e.g., Kekre and Srinivasan 1990, Lancaster 1990). Supporting the theory that shoppers like assortment, in certain product categories a decrease in variety has been appeared to prompt to decrease sales (Borle et al. 2005).

Most of the focus of the studies has been to explore the optimal ways of implementing the product variety strategy; the overall effect of product variety on operational and sales performance has mainly been unnoticed. Our 
research examines the impact of product variety on both operational and sales performance using data from a retailer operating multiple under multiple modes i.e. distribution and reseller.

\section{Data and Variable Description}

We use transaction sales data from one of the biggest Chinese retailer store chain in China Hubei Province. The data drawn from their internal database comprise of 41 months. It includes the information about sales of products belonging to cosmetics and washing product, tissues and textile category and containing over 7000 products at a time. All of these three categories are operated under Distribution and Reseller mode. In reseller mode the retailer acts in a traditional way, buy products from manufacturer/supplier and then sell them to customer. In Distribution mode the product inventory and pricing is control by the manufacturer/supplier and retailer get paid as some percentage of total revenue for using the retailer shelf.

Our raw data contained over 180,000 observations in these non-food categories. After initial data inspection and cleaning missing and duplicated observations were removed. For the purpose of this study we only selected those brands, which were contributing more to the sale revenue generation. We also excluded those products/brands from our dataset, which were not available in our store for more than 6 months during period of 2013-2016. We compared the product variety and inventory turnover of selected products with the overall category and didn't find any significant change. Therefore we believe that the omission of other products/brands should not have a substantial effect on the empirical results.

Our final dataset contains almost 110,000 observations in cosmetics, textile and tissues section. Tables below present summary statistics of our final dataset.

\section{Research Hypothesis \& Model Specification}

In this section of article we prepare the hypotheses to relate the product variety with Inventory turnover and sale in different mode of operations. A significant characteristic of our model is determining the effect in distribution and reseller channel structure rather than retailer as one channel. This is done because each channel structure has their own behavior, which can affect operation performances variables differently.

\section{HYPOTHESIS 1: Product Variety is negatively correlated with Inventory turnover.}

Keeping the total demand constant, an increase in product variety will increase the inventory level (Kekre and Srinivasan 1990). According to 
formula of inventory turnover, an increase in inventory level will decrease inventory turnover, which provides basis for our hypothesis.

\section{HYPOTHESIS 2: Product Variety is positively correlated with sales.}

If large variety of product has been provided to customer, it will increase the probability of completing the sale because out of high assortment diverse customers will find what they are looking for (Kekre and Srinivasan, 1990; Xia and Rajagopalam, 2009). So based on customer segmentation and variety-seeking, high variety strategy has been proposed as a way to increase sale performance.

We will be testing these two hypotheses for different mode of operations. According to our knowledge both of these hypothesis have been tested in literature only for reseller mode, while there is lack of empirical verification of these hypothesis. In our study we will empirically analyze the correlation of product variety with inventory turnover and sales for distribution mode.

We will be testing our hypothesis by applying linear regression for studying the relation of product variety with inventory turnover and sales.

\section{Results}

Table 1,2,3 shows the linear regression model for cosmetics \& washing products, Textile and Tissues categories in distribution and reseller mode respectively. In reseller for cosmetics and washing products, product variety is negatively correlated with Inventory turnover and sales. Which shows that maybe retailer is not very effective in offering product variety and offering too many choices to the customer results in customer confusion that results in decrease in sale. While in distribution mode the supplier offer very distinctive product variety and increase in variety results in high sales, which contributes toward high inventory turnover. Also for textile category high product variety resulted in high inventory turnover and sales in both distribution and reseller mode. But for tissues category the situation was reverse, product variety is found to have negative correlation with Inventory Turnover and positive correlation with Sale for both distribution and reseller mode. This difference in correlation between different categories and mode of operations can be because of how the consumer perceives product variety for different kind of products. For some product like cosmetics and textile consumer can be enticed by variety and which will result in higher sales and inventory turnover. But for products like tissues variety doesn't make much difference in consumer perception and increase in variety will still keep the demand same, which will increase the inventory, level and decrease the inventory turnover. 
Table 1

\begin{tabular}{|c|c|c|}
\hline \multicolumn{3}{|c|}{$\begin{array}{l}\text { Cosmetics and Washing products } \\
\text { Dependent variabl }\end{array}$} \\
\hline & \multicolumn{2}{|c|}{ Product Variety } \\
\hline & (Distribution Mode) & (Reseller Mode) \\
\hline Inventory Turnover & $\begin{array}{l}1.388^{* * *} \\
(0.137)\end{array}$ & $\begin{array}{l}-0.315^{* *} \\
(0.124)\end{array}$ \\
\hline Sale quantity & $\begin{array}{l}0.008^{*} \\
(0.005)\end{array}$ & $\begin{array}{c}-0.048^{* * *} \\
(0.004)\end{array}$ \\
\hline Constant & $\begin{array}{c}69.277^{* * *} \\
(0.232)\end{array}$ & $\begin{array}{c}48.099^{* * *} \\
(0.201)\end{array}$ \\
\hline Observations & 38,046 & 38,161 \\
\hline $\mathrm{R}^{2}$ & 0.38 & 0.4 \\
\hline Adjusted $\mathrm{R}^{2}$ & 0.38 & 0.4 \\
\hline Note: & ${ }^{*} \mathrm{p}<0.1$ & $<0.01$ \\
\hline
\end{tabular}

Table 2

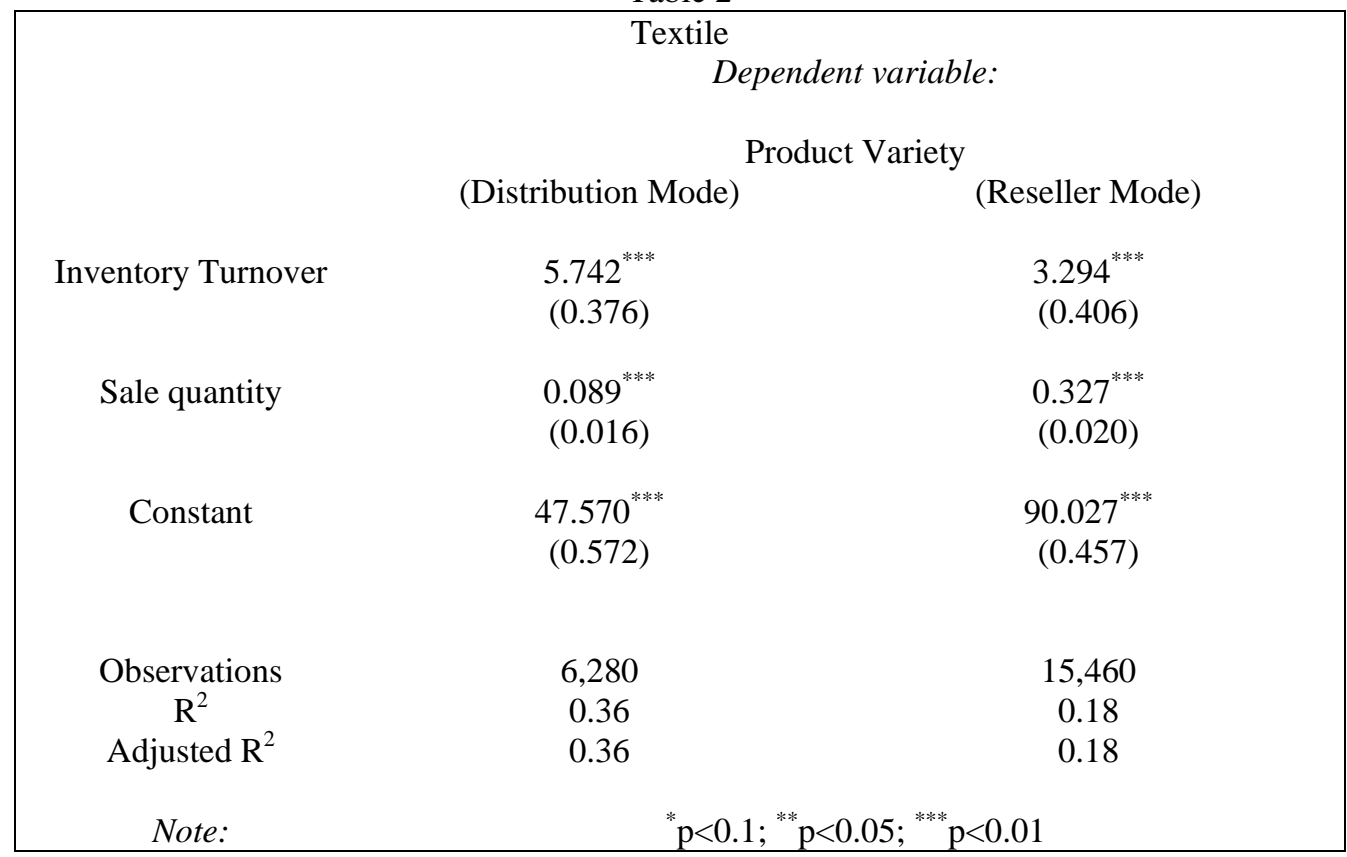


Table 3

\begin{tabular}{|c|c|c|}
\hline \multicolumn{3}{|c|}{ Dependent variable: } \\
\hline & $\begin{array}{c}\text { Proc } \\
\text { (Distribution Mode) }\end{array}$ & (Reseller Mode) \\
\hline Inventory Turnover & $\begin{array}{l}-0.385^{* *} \\
(0.194)\end{array}$ & $\begin{array}{l}-1.530^{* * *} \\
(0.381)\end{array}$ \\
\hline Sale quantity & $\begin{array}{l}0.032^{* * *} \\
(0.003)\end{array}$ & $\begin{array}{l}0.018^{* *} \\
(0.009)\end{array}$ \\
\hline Constant & $\begin{array}{l}55.237^{* * *} \\
(0.333)\end{array}$ & $\begin{array}{c}36.538^{* * *} \\
(0.564)\end{array}$ \\
\hline $\begin{array}{c}\text { Observations } \\
\mathrm{R}^{2} \\
\text { Adjusted } \mathrm{R}^{2}\end{array}$ & $\begin{array}{c}10,356 \\
0.14 \\
0.14\end{array}$ & $\begin{array}{c}1,726 \\
0.20 \\
0.19\end{array}$ \\
\hline Note: & ${ }^{*} \mathrm{p}<0.1$; & 01 \\
\hline
\end{tabular}

\section{Conclusion}

Distribution mode has been getting popularity in retailing sector of China. Previously the effect of price and sales has been studied on inventory turnover in multiple modes of operation. Our research analyzed the impact product variety has on inventory turnover and sales in different categories of product under these multiple modes of operation.

Our study is distinctive from previous research in that we analyzed the correlation between product variety and inventory turnover for different kind of products in different channel structure. Which showed us that these metrics doesn't affect each other in the same way for different categories in different settings. For products that attract variety-seeking customers (cosmetics and textile) they show positive relation between product variety and inventory turnover. So increase in product variety in these categories improves the sale performance and inventory turnover. On the other hand for products like tissues in which variety is not major attribute for customer the relationship is negative with inventory turnover.

Moreover for cosmetic and washing product variety there is difference in relationship between product variety and inventory over for distribution and reseller mode. Distribution mode proves to be more effect and efficient in applying product variety strategy than reseller mode which makes inventory turnover and sales performance better in distribution mode. This is usually because that the high-end cosmetic brands (e.g. Schwarzkopf \& L'Oreal) operate in distribution mode and customer perceives product variety favorably for these kinds of brands. 
There are few limitations in this study that can be addressed in future studies using more detailed datasets from multiple retailers. First limitation is that our dataset is from on retailer so it will be better to test these models across different retailers to confirm the results of this study.

Secondly our data is aggregate at category level, but there can be many sub-categories within each category and they might exhibit different behavior. So for future study we would like to study the relation between product variety and inventory turnover at sub-category level.

\section{References:}

1. Abhishek, V., Jerath, K., \& Zhang, Z. J. (2015). Agency selling or reselling? Channel structures in electronic retailing. Management Science.

2. Alfaro, J. A., \& Corbett, C. J. (2003). The value of SKU rationalization in practice (the pooling effect under suboptimal inventory policies and nonnormal demand). Production and Operations Management, 12(1), 12-29.

3. Baumol, W. J., \& Ide, E. A. (1956). Variety in retailing. Management Science, 3(1), 93-101.

4. Bayus, B. L., \& Putsis Jr, W. P. (1999). Product proliferation: An empirical analysis of product line determinants and market outcomes. Marketing Science, 18(2), 137-153.

5. Berry, W. L., \& Cooper, M. C. (1999). Manufacturing flexibility: methods for measuring the impact of product variety on performance in process industries. Journal of Operations Management, 17(2), 163-178.

6. Bils, M., \& Klenow, P. J. (2001). The acceleration in variety growth. The American Economic Review, 91(2), 274-280.

7. Borle, S., Boatwright, P., Kadane, J. B., Nunes, J. C., \& Galit, S. (2005). The effect of product assortment changes on customer retention. Marketing science, 24(4), 616-622.

8. Cachon, G. P., Terwiesch, C., \& Xu, Y. (2006). The impact of consumer search, firm entry and competition on assortment and pricing. Marketing Science Forthcoming.

9. Closs, D.J., Jacobs, M.A., Swink, M., Webb, G.S., 2008. Toward a theory of competencies for the management of product complexity: Six case studies. Journal of Operations Management 26(5) 590-610.

10. Dana Jr, J. D., \& Petruzzi, N. C. (2001). Note: The newsvendor model with endogenous demand. Management Science, 47(11), 14881497. 
11. Fisher, M. L., \& Ittner, C. D. (1999). The impact of product variety on automobile assembly operations: Empirical evidence and simulation analysis. Management science, 45(6), 771-786.

12. Ho, T. H., \& Tang, C. (1998). Research Advances in Product Variety Management.

13. Jerath, K., Z. J. Zhang. 2010. Store-within-a-store. J. Mark. Res. 47(4): 748-763.

14. Kekre, S., \& Srinivasan, K. (1990). Broader product line: a necessity to achieve success?. Management science, 36(10), 1216-1232.

15. Larson, P. D., \& DeMarais, R. A. (1990). Psychic stock: An independent variable category of inventory. International Journal of Physical Distribution \& Logistics Management, 20(7), 28-34.

16. Li, J., Chan, T. Y., \& Lewis, M. (2016). What Happens When Manufacturers Perform The Retailing Functions?. Production and Operations Management.

17. Osnos, E. (1997). Too many choices? Firms cut back on new products. Philadelphia Inquirer, 27.

18. Ryzin, G. V., \& Mahajan, S. (1999). On the relationship between inventory costs and variety benefits in retail assortments. Management Science, 45(11), 1496-1509.

19. Schwartz, B. 2000. Self-determination: the tyranny of freedom. American Psychologist 55(1) 79-88.

20. Silver E. A., D. F. Pyke., R. Peterson. 1998. Inventory Management and Production Planning and Scheduling. Third Edition, John Wiley \& Sons, Inc., New York.

21. Smith, S. A., \& Agrawal, N. (2000). Management of multi-item retail inventory systems with demand substitution. Operations Research, 48(1), 50-64.

22. Thompson, D. V., Hamilton, R. W., Rust, R. T. 2005. Feature fatigue: When product capabilities become too much of a good thing. Journal of Marketing Research 42(November ) 431-442.

23. Ton, Z., \& Raman, A. (2010). The effect of product variety and inventory levels on retail store sales: A longitudinal study. Production and Operations Management, 19(5), 546-560.

24. Wagner, S. M., \& Friedl, G. (2007). Supplier switching decisions. European Journal of Operational Research, 183(2), 700-717.

25. Wan, X., Evers, P. T., \& Dresner, M. E. (2012). Too much of a good thing: The impact of product variety on operations and sales performance. Journal of Operations Management,30(4),316-324.

26. Xia, N., \& Rajagopalan, S. (2009). Standard vs. custom products: variety, lead time, and price competition. Marketing science, 28(5), 887-900. 
27. Zahorik, A. J., 1994. A nonhierarchical brand switching model for inferring market structure. European Journal of Operational Research 76 (2), 344-358. 